\section{'La Belle' Peach}

\section{Charles E. Johnson ${ }^{1}$ and Edward W. Bush ${ }^{2}$}

Louisiana State University Agricultural Center, Agricultural Experiment Station, Department of Horticulture, 137 Julian C. Miller Hall, Baton Rouge, LA 70803-2120

Additional index words. Prunus persica, chilling requirement, fruit breeding, drupe

'La Belle' is a yellow flesh, freestone peach [Prunus persica (L) Batsch] for freshmarket use requiring about $600 \mathrm{~h}$ below 7.2 ${ }^{\circ} \mathrm{C}$ to satisfy dormancy in buds. 'La Belle' is the twenty fourth cultivar released from the Louisiana State University Agricultural Center (LSU AgCenter), Clinton, peach breeding program. The peach breeding project was initiated in the 1940s to develop cultivars adapted to the lower and Gulf southern U.S. region. Fruit of this cultivar are freestone with melting flesh suitable for local sales and longdistant shipping. This selection ripens about 3 July in central Louisiana about $10 \mathrm{~d}$ after ' $\mathrm{La}$ Feliciana' (Hawthorne et al., 1980).

\section{Origin}

'La Belle'first fruited in 1976 and was tested as L73-A20-17. This selection was evaluated at the LSU AgCenter's Idlewild Research Station, Clinton (lat. $30^{\circ} 49^{\prime} 08^{\prime} \mathrm{N}$ and long. $90^{\circ}$ $58^{\prime} 40^{\prime} \mathrm{W}$ ). Additional evaluations were made at grower locations in southern Louisiana and research stations in Georgia. The original tree was selected by P.L. Hawthorne (professor emeritus) from a group of seedlings derived from a 1973 cross of 'Dixiland' and L63-17-13. A complete pedigree is presented in Fig. 1.

\section{Description and Performance}

Trees of 'La Belle' were grown in a research orchard at the LSU AgCenter Idlewild Research Station. Annual evaluations were made on the original tree and on additional trees budded to 'Lovell' rootstock. Data were also obtained from trees growing in two tree plots replicated three times in an orchard alongside elite selections and locally recommended cultivars. Trees in the orchard were trained to an open center form. Recommended cultural practices and nutrients were applied to the entire orchard according to extension service recommendations (Puls et al., 1994). When properly thinned to $15 \mathrm{~cm}$ apart, 'La Belle' produces 75 -mm-diameter fruit (125 to 225 g) with yellow flesh and some red flesh near the suture and pit areas. The primary surface color is yellow with about $70 \%$ bright red over-

Received for publication 13 July 2004. Accepted for publication 18Aug. 2004. Louisiana State University AgCenter journal series 01-28-0660. We appreciate technical assistance and advice of Kristi Whitley. We thank David Himelrick, Jeff Kuehny, and P.W. Wilson for manuscript review.

${ }^{1}$ Professor of horticulture, to whom reprints requests should be addressed; e-mail cejohnson@agctr.lsu.edu. ${ }^{2}$ Associate professor. color. Fruit are round to slightly oval in shape (Fig. 2). The fruit shape and size is similar to 'Dixiland' cultivar. The fruit is uniformly firm on cheek at suture and side opposite suture. Pubescence is short and nonobjectionable for marketing field-packed fruit for local markets. Auniform rating system of recording information was used to rate fruiting characteristics of each cultivar and selection independently. Over a 10-year period 'La Belle' consistently produced firm, attractive fruit with a mean score $8.2 \pm 0.7$ and $8.3 \pm 0.6$ respectively, out a possible 10 . There were no notations of split pits in the records of this selection for cultivars 1990-2000, Clinton, La.

y Julian calendar dates the 12-year period of 1988-2000. Fruit of this selection ripens first week of July or about 10 d after 'La Feliciana' (Hawthorne et al., 1980) in Clinton (Table 1).

This selection has been observed to have excellent internal color retention with a very slight amount of browning after $1 \mathrm{~h}$ at room temperature $\left(22^{\circ} \mathrm{C}\right)$. The pit completely separates from the flesh when ripe.

Pubescence is short and nonobjectionable for marketing field-packed fruit for local markets. In ratings and observations made from 1990-2000, 'La Belle' consistently scored high for quality attributes such as texture and taste (Table 3 ). The sugar to acid ratio of this selection is comparable and sometimes higher than other cultivars in the same ripening season. The fruit would be considered an acid type for processing purposes.

Leaves are medium large with small serration on margins. Two to four small reniformshaped glands are located at the leaf base and petiole. Trees are vigorous and have shown no tendency toward excessive sun scald or cold damage. Fruit and leaf buds require about 600 $\mathrm{h}$ below $7.2{ }^{\circ} \mathrm{C}$ during the dormant period to
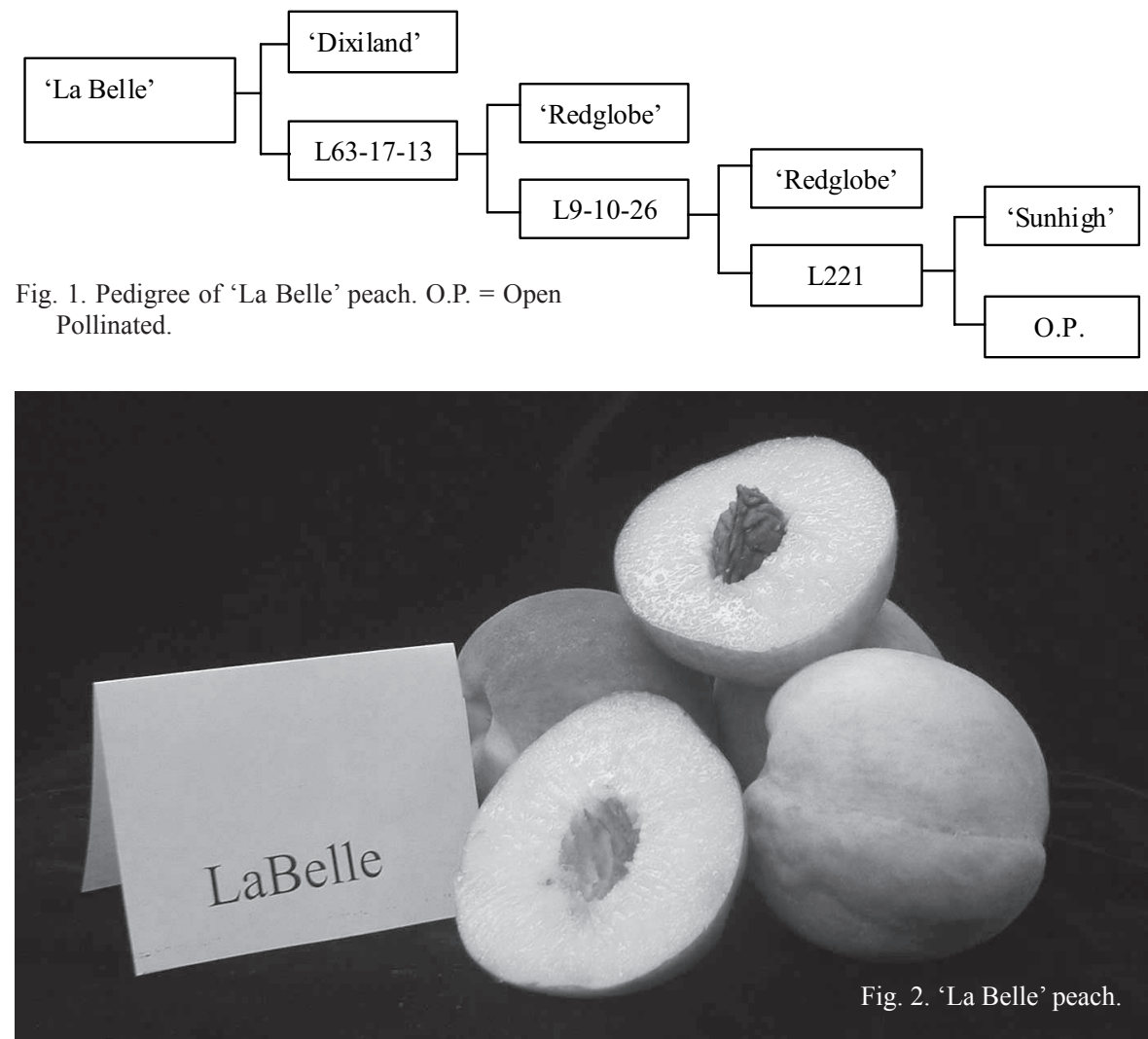

Table 1. Comparison of full bloom and fruit ripening dates of 'La Belle'with 'La Feliciana' and 'La White'

\begin{tabular}{lcccc}
\hline Selection & $\begin{array}{c}\text { Years of } \\
\text { observation } \\
\text { (no.) }\end{array}$ & $\begin{array}{c}\text { Mean } \\
\text { harvest } \\
\text { date }^{\mathrm{z}}\end{array}$ & $\begin{array}{c}\text { Mean date } \\
\text { of full } \\
\text { bloom }^{\mathrm{y}}\end{array}$ & $\begin{array}{c}\text { Estimated } \\
\text { chill hours } \\
\text { required }^{\mathrm{x}}\end{array}$ \\
\hline La Feliciana & 10 & $176 \pm 7.2$ & $60 \pm 5.5$ & 550 \\
La White & 10 & $161 \pm 5.2$ & $78 \pm 7.1$ & 650 \\
La Belle & 10 & $184 \pm 7.7$ & $74 \pm 5.2$ & 600 \\
\hline
\end{tabular}

${ }^{2}$ Dates of full bloom are over the same ten year period for all cultivars.

${ }^{\mathrm{x}}$ Chilling hour requirement was estimated by comparing the time of full bloom to cultivars of known chilling requirement, i.e., 'La Feliciana and 'La White' for the same 10-year period. 
Table 2. Comparison of 'La Belle' fruit to standard cultivars in total sugar and acid composition, Clinton, La. Five uniformly ripe fruit were harvested from each of three trees in Summer 2000. Each tree was a replication. Five fruit from each tree were peeled, macerated, and blended together before samples were taken.

\begin{tabular}{|c|c|c|c|c|}
\hline Variety & $\mathrm{pH}$ & $\begin{array}{c}\text { Soluble } \\
\text { solids }^{z} \\
(\%)\end{array}$ & $\begin{array}{c}\text { Titratable } \\
\text { acidity }^{\mathrm{y}} \\
(\%)\end{array}$ & $\begin{array}{l}\text { Solids to } \\
\text { acids } \\
\text { ratio }\end{array}$ \\
\hline Hawthorne & 4.1 & $14.6 \mathrm{a}^{\mathrm{x}}$ & $0.6 \mathrm{a}$ & $24.3 .0 \mathrm{a}$ \\
\hline Dixiland & 4.29 & $18.1 \mathrm{~b}$ & $0.7 \mathrm{a}$ & $25.4 \mathrm{a}$ \\
\hline La Belle & 4.40 & $15.9 \mathrm{a}$ & $0.5 \mathrm{a}$ & $31.2 \mathrm{a}$ \\
\hline
\end{tabular}

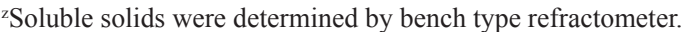

Titratable acidity was determined by titrating a 10-mL sample to an end point $\mathrm{pH} 8.1$.

${ }^{x}$ Means followed by the same letter within a column are not significantly different according to Duncan's test $(P \leq 0.05)$.

satisfy the chilling requirement during dormancy (Table 2).

\section{Disease Characteristics}

Trees of 'La Belle'were grown in a research orchard alongside cultivars that were susceptible to bacterial spot caused by Xanthamonas campestris pv pruni (Smith) Dye. 'La Belle' has shown slight susceptibility to bacterial spot on both leaves and fruit in years when the incidence of disease was high on surrounding trees of susceptible cultivars.

\section{Recommendations}

'La Belle' is recommended for commercial and home orchard planting where a good quality, large fruited freestone cultivar is needed that ripens about $5 \mathrm{~d}$ before 'Dixiland' (Table 2) requiring about $600 \mathrm{~h}$ of chilling, which is slightly less than 'Dixiland'. This cultivar will help to fill a gap between 'La Feliciana' and 'Dixiland' with a moderate chill requirement.

\section{Availability}

Nursery trees of this cultivar are not available from the LSU AgCenter. Commercial nurseries will be furnished bud wood on a first-come basis for the production of nursery trees.

\section{Literature Cited}

Hawthorne, P.L., W.A. Young, J.C. Taylor, T.J. Raiford, F.J. Peterson and D.W. Newsom, 1980. 'La Feliciana' Peach. Louisiana Agricultural Experiment Station Cir. No. 111.

Puls, Earl, C. E. Johnson, Bill Hadden. 1994. 'Louisiana Commercial Peach Production'. Louisiana Cooperative Extension Service Pub. 2489. 